\title{
Efficacy and Safety of SGLT-2 Inhibitors for Treatment of Diabetes Mellitus among Kidney Transplant Patients: A Systematic Review and Meta-Analysis
}

\author{
Api Chewcharat $1,2, * \mathbb{1}$, Narut Prasitlumkum ${ }^{3}$, Charat Thongprayoon ${ }^{2, *}$, Tarun Bathini ${ }^{4}$, \\ Juan Medaura ${ }^{5}$, Saraschandra Vallabhajosyula ${ }^{6}$ and Wisit Cheungpasitporn $2,5, *$ (D) \\ 1 Department of Medicine, Mount Auburn Hospital, Harvard Medical School, Cambridge, MA 02138, USA \\ 2 Department of Medicine, Division of Nephrology and Hypertension, Mayo Clinic, \\ Rochester, MN 55905, USA \\ 3 Department of Medicine, University of Hawaii, Honolulu, HI 96822, USA; narutprasitlumkum@gmail.com \\ 4 Department of Internal Medicine, University of Arizona, Tuscon, AZ 85721, USA; tarunjacobb@gmail.com \\ 5 Department of Internal Medicine, Division of Nephrology, University of Mississippi Medical Center, \\ Jackson, MS 39216, USA; jmedaura@umc.edu \\ 6 Section of Interventional Cardiology, Department of Medicine, Division of Cardiovascular Medicine, \\ Emory University School of Medicine, Atlanta, GA 30322, USA; saraschandra.vallabhajosyula@emory.edu \\ * Correspondence: api.che@hotmail.com (A.C.); charat.thongprayoon@gmail.com (C.T.); \\ wcheungpasitporn@gmail.com (W.C.)
}

Received: 10 September 2020; Accepted: 16 November 2020; Published: 17 November 2020

\begin{abstract}
Background: The objective of this systematic review was to evaluate the efficacy and safety profiles of sodium-glucose co-transporter 2 (SGLT-2) inhibitors for treatment of diabetes mellitus (DM) among kidney transplant patients. Methods: We conducted electronic searches in Medline, Embase, Scopus, and Cochrane databases from inception through April 2020 to identify studies that investigated the efficacy and safety of SGLT-2 inhibitors in kidney transplant patients with DM. Study results were pooled and analyzed utilizing random-effects model. Results: Eight studies with 132 patients (baseline estimated glomerular filtration rate (eGFR) of $64.5 \pm 19.9 \mathrm{~mL} / \mathrm{min} / 1.73 \mathrm{~m}^{2}$ ) treated with SGLT-2 inhibitors were included in our meta-analysis. SGLT-2 inhibitors demonstrated significantly lower hemoglobin $\mathrm{A} 1 \mathrm{c}(\mathrm{HbA} 1 \mathrm{c})(\mathrm{WMD}=-0.56 \%$ [95\%CI: $-0.97,-0.16] ; p=0.007)$ and body weight (WMD $=-2.16 \mathrm{~kg}[95 \% \mathrm{CI}:-3.08,-1.24] ; p<0.001$ ) at end of study compared to baseline level. There were no significant changes in eGFR, serum creatinine, urine protein creatinine ratio, and blood pressure. By subgroup analysis, empagliflozin demonstrated a significant reduction in body mass index (BMI) and body weight. Canagliflozin revealed a significant decrease in $\mathrm{HbA1C}$ and systolic blood pressure. In terms of safety profiles, fourteen patients had urinary tract infection. Only one had genital mycosis, one had acute kidney injury, and one had cellulitis. There were no reported cases of euglycemic ketoacidosis or acute rejection during the treatment. Conclusion: Among kidney transplant patients with excellent kidney function, SGLT-2 inhibitors for treatment of $\mathrm{DM}$ are effective in lowering $\mathrm{HbA1C}$, reducing body weight, and preserving kidney function without reporting of serious adverse events, including euglycemic ketoacidosis and acute rejection.
\end{abstract}

Keywords: SGLT-2 inhibitors; kidney transplant; renal transplant; transplantation; meta-analysis

\section{Introduction}

Diabetes mellitus (DM) is the leading cause of end-stage kidney disease (ESKD) worldwide [1]. In the United States, Organ Procurement Transplant Network/Statistics on Donation and Transplantation in the United States (OPTN/SRTR) reported that nearly $40 \%$ of patients on transplant waiting list in 
2018 had DM with an ongoing upward trend [2]. In addition, approximately $15-30 \%$ of nondiabetic kidney transplant recipients develop new-onset diabetes after transplant [3-5], resulting in a high prevalence of kidney transplant recipients with preexisting and post-transplant diabetes mellitus (PTDM), ranging up to $74 \%$ depending on country, ethnicity, and criteria of diagnosis [6,7]. DM among kidney transplant recipients has been associated with higher rates of cardiovascular disease, infectious complications, graft loss, and mortality [8-11]. Hence, controlling blood sugar is necessary in order to prevent these poor outcomes among kidney transplant recipients [12]. Lifestyle modifications, including dietary modification, weight reduction, and exercise, along with pharmacologic treatment, are required for treatment of DM among kidney transplant recipients [13,14].

Sodium-glucose co-transporter 2 (SGLT-2) inhibitors are novel oral glucose-lowering medications that inhibit glucose reabsorption in the proximal tubule and promote renal excretion of glucose [15]. Glycemic efficacy of SGLT-2 inhibitors is considered to be relatively weak compared to other glucose-lowering medications with $0.4 \%$ to $1.1 \%$ reduction in hemoglobin $\mathrm{A} 1 \mathrm{C}$ (HbA1c) levels [16-18]. This glucose-lowering effect is independent of beta-cell function and insulin sensitivity [19]. Thereby, SGLT-2 inhibitors do not generally cause hypoglycemia [20-23]. Recent meta-analyses demonstrated the cardio- and renal protective effects such as reduce the progression of diabetic nephropathy, diminish cardiovascular mortality, lower rates of hospitalized heart failure, and decrease weight among patients with DM [24-26]. Nevertheless, some adverse effects of SGLT-2 inhibitors have been reported, such as urinary tract infection, genital mycosis, acute kidney injury (AKI), hypotension, bone fracture, diabetic ketoacidosis, and amputation [27-30]. However, most of the studies that reported these efficacious and adverse effects focused on only the non-kidney transplant population [31-46]. The efficacy and safety data for the use of SGLT-2 inhibitors in kidney transplant recipients with DM remain unclear.

Therefore, we conducted the present systematic review and meta-analysis to assess the efficacy and safety of SGLT-2 inhibitors for treatment of DM among kidney transplant recipients.

\section{Materials and Methods}

\subsection{Data Sources and Search Strategies}

A comprehensive search of several databases from each database's inception to 30 April 2020, any language, was conducted. The databases included Ovid MEDLINE(R) and Epub Ahead of Print, In-Process and Other Non-Indexed Citations, Daily, Ovid EMBASE, Ovid Cochrane Central Register of Controlled Trials, Ovid Cochrane Database of Systematic Reviews, and Scopus. The search strategy was designed and conducted by an experienced librarian with input from the study's principal investigator. Controlled vocabulary supplemented with keywords was used to search for studies of SGLT-2 inhibitors in kidney transplant patients. The actual strategy listing all search terms used is available in the Supplementary Materials. This study was conducted by the Preferred Reporting Items for Systematic Reviews and Meta-Analysis (PRISMA) statement [47].

\subsection{Study Selection}

Given limited data, our study included any studies, including case series and randomized controlled trials, examining the efficacy and safety of any SGLT-2 inhibitors among kidney transplant patients. We excluded case reports or animal studies. Case series were defined as a study that included multiple cases receiving SGLT-2 inhibitors without a control group. For cohort studies or randomized controlled trials, we focused only on treatment group with SGLT-2 inhibitors in order to be comparable and consistent with case series. The quality assessment tool for case series studies proposed by the National Heart, Lung, and Blood Institute (NHLBI) was used to rate the quality [48]. Studies with a score of $0-3,4-6$, and $\geq 7$ were considered as low, fair, and good quality, respectively. There were no restrictions on language, sample size, or study duration.

Retrieved articles were individually reviewed for eligibility by two investigators (A.C. and N.P.) utilizing a systematic review management program called Covidence, which has been selected by 
Cochrane to become a standard production platform for their reviews. Disagreements were addressed and resolved by third investigator (W.C.).

\subsection{Data Extraction}

The following data were extracted: first author name, year of publication, number of participants in SGLT-2 inhibitors group, duration of follow-up, types of SGLT-2 inhibitors, mean age, sex, and duration of transplantation. Efficacy outcomes included estimated glomerular filtration rate (eGFR), serum creatinine, urine protein-creatinine ratio, $\mathrm{HbA1C}$, systolic blood pressure (SBP), diastolic blood pressure (DBP), body mass index (BMI), and body weight. Safety profile outcomes included incidence of urinary tract infection, genital mycosis, euglycemic ketoacidosis, acute kidney injury, acute rejection, ulcer, and cellulitis.

\subsection{Data Synthesis and Statistical Analysis}

A random-effects model was used due to the expected clinical heterogeneity in the included populations. We calculated weight mean difference (WMD) for the difference in mean value between baseline and at the end of study for continuous variables among SGLT-2 inhibitors group. All pooled estimates were shown with $95 \%$ confidence intervals (CIs). Heterogeneity among effect sizes estimated by individual studies was described with the $\mathrm{I}^{2}$ statistic and the chi-square test. A value of $\mathrm{I}^{2}$ of $0 \%$ to $25 \%$ represents insignificant heterogeneity, $26 \%$ to $50 \%$ low heterogeneity, $51 \%$ to $75 \%$ moderate heterogeneity, and 76 to $100 \%$ high heterogeneity [49].

Publication bias was evaluated using funnel plots, and the Egger test was used to assess the asymmetry of the funnel plot. A $p$-value of less than 0.05 indicates the presence of publication bias. The meta-analysis was performed by STATA/IC 14.1 (StataCorp LLC, Lakeway, TX, USA).

\section{Results}

\subsection{Characteristics and Quality of Studies}

A total of 119 potentially relevant articles were identified and screened. Fourteen articles were assessed in detail, of which 8 studies with 132 participants fulfilled the eligibility criteria and were included in our meta-analysis (Figure 1).

Characteristics of each study were shown in Table 1. One study was randomized controlled trial [43], while the other seven studies were categorized as case series [50-55]. Given these different study designs, we extracted data from only treatment group for the randomized controlled trial and compared each parameter level between at baseline and the end of study. Sample sizes of the treatment group among 8 studies ranged from 8 to 22 participants. The mean age of patients ranged from 46 to 66 years old. Time after kidney transplantation varied from 3 to 20 years. Baseline eGFR among all included patients was $64.5+/-19.9 \mathrm{~mL} / \mathrm{min} / 1.73 \mathrm{~m}^{2}$.

In terms of the quality assessment, seven studies [43,50-55] were graded as good and only one study [56] was graded as fair. There were no poor-quality studies. 


\section{PRISMA Flow Diagram}
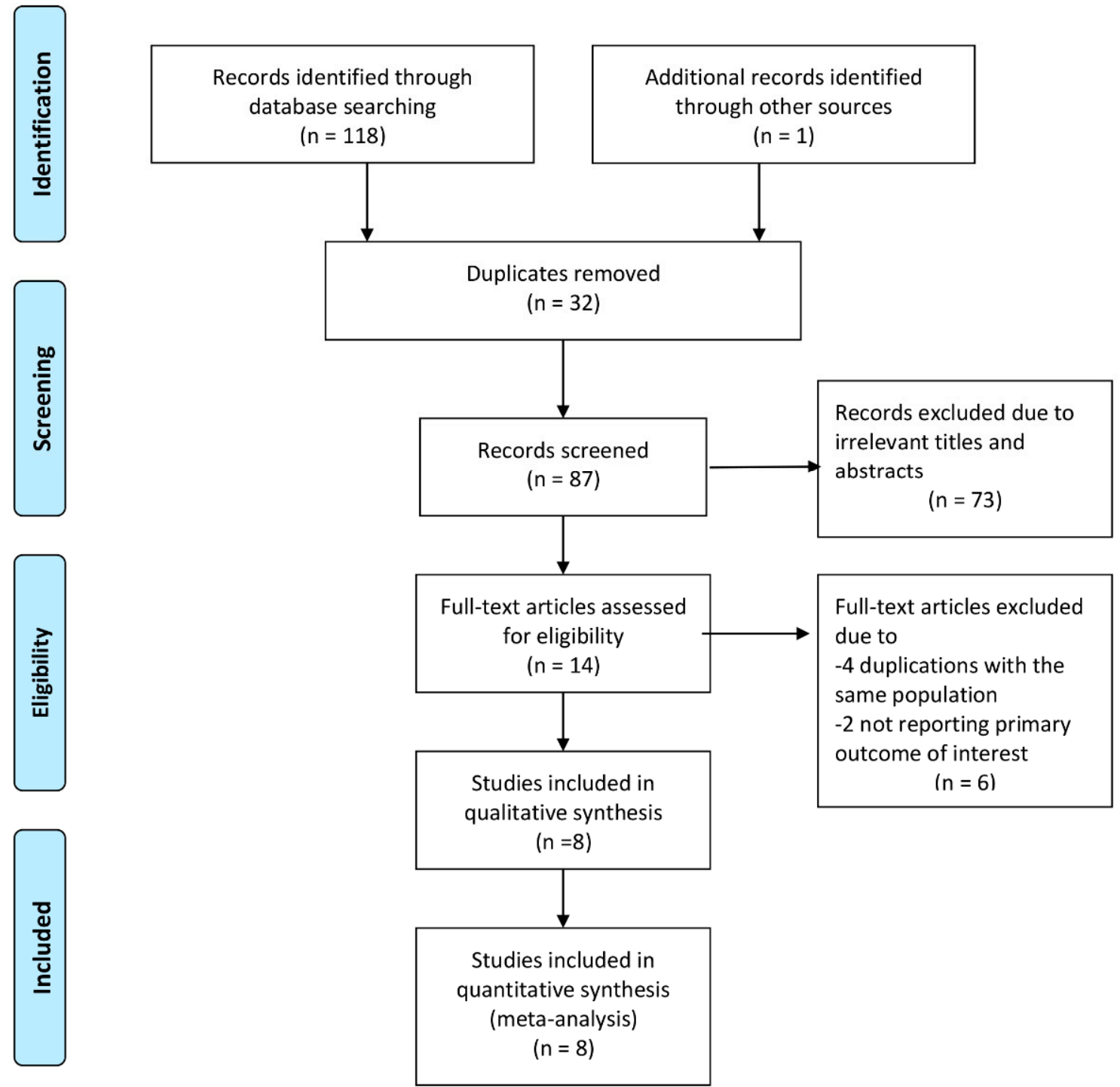

Figure 1. Flow diagram for study selection. 
Table 1. Characteristics of the included studies in this meta-analysis analyzing the efficacy and safety profiles of sodium-glucose co-transporter 2 (SGLT-2) inhibitors on treating kidney transplant recipients with post-transplant diabetes mellitus.

\begin{tabular}{|c|c|c|c|c|c|c|c|c|c|c|c|}
\hline Authors & Country & $\begin{array}{l}\text { Treatment } \\
\text { Medication }\end{array}$ & $\begin{array}{c}\text { Number of Participants } \\
\text { Treated with SGLT-2 } \\
\text { Inhibitors }\end{array}$ & $\begin{array}{l}\text { Mean Age } \\
\text { (Years) }\end{array}$ & \%Male & $\begin{array}{c}\% \mathrm{DM} \\
\text { Prior to KT }\end{array}$ & $\begin{array}{c}\mathrm{F} / \mathrm{U} \\
\text { (Months) }\end{array}$ & $\begin{array}{l}\text { GFR Baseline } \\
\left(\mathrm{mL} / \mathrm{min} / 1.73 \mathrm{~m}^{2}\right)\end{array}$ & HbA1C & $\begin{array}{l}\text { Transplant } \\
\text { Duration } \\
\text { (Years) }\end{array}$ & $\begin{array}{c}\text { Quality } \\
\text { Assessment }\end{array}$ \\
\hline Rajasekeran 2017 [50] & Canada & Canagliflozin & 10 & $56.7 \pm 12.4$ & $70 \%$ & $80 \%$ & 8 & $70.8 \pm 18.3$ & $8.1 \pm 1.4$ & $4.0 \pm 3.4$ & good \\
\hline Schwaiger 2018 [51] & Austria & Empagliflozin & 8 & $56.5 \pm 7.9$ & $50 \%$ & $0 \%$ & 12 & $54.0 \pm 23.8$ & $6.7 \pm 0.7$ & $5.8 \pm 4.8$ & good \\
\hline Alkindi 2019 [52] & UAE & $\begin{array}{l}\text { Empagliflozin } \\
\text { or } \\
\text { Dapagliflozin }\end{array}$ & 8 & $56.8 \pm 13.7$ & $75 \%$ & $25 \%$ & 24 & $75.8 \pm 13.4$ & $9.3 \pm 1.4$ & $9.6 \pm 6.4$ & good \\
\hline Attallah 2019 [53] & UAE & Empagliflozin & 8 & $45.9 \pm 6.6$ & $50 \%$ & $50 \%$ & 12 & NR & $8.1 \pm 0.2$ & $19.9 \pm 6.0$ & good \\
\hline \multirow{2}{*}{ Halden 2019 [43] } & \multirow{2}{*}{ Norway } & Empagliflozin & 22 & 63 & $77 \%$ & $0 \%$ & 6 & $66 \pm 10.5$ & $6.9 \pm 0.4$ & 3 & \multirow{2}{*}{ good } \\
\hline & & Placebo & 22 (control) & 59 & $77 \%$ & $0 \%$ & 6 & $59 \pm 9.5$ & $6.8 \pm 0.3$ & 3 & \\
\hline Kong 2019 [56] & $\begin{array}{l}\text { South } \\
\text { Korea }\end{array}$ & Dapagliflozin & 42 & NR & NR & NR & 12 & $60.3 \pm 17$ & $7.5 \pm 1.1$ & NR & fair \\
\hline Mahling 2019 [54] & Germany & Empagliflozin & 10 & $66.0 \pm 12.6$ & $80 \%$ & $30 \%$ & 12 & $57 \pm 19.3$ & $7.3 \pm 1.0$ & $5.9 \pm 3.3$ & good \\
\hline Shah 2019 [55] & India & Canagliflozin & 24 & $53.8 \pm 7.1$ & $96 \%$ & $83 \%$ & 6 & $86 \pm 20$ & $8.5 \pm 1.5$ & 2.7 & good \\
\hline
\end{tabular}

NR, not reported; UAE, United Arab Emirates. 


\subsection{Efficacy of SGLT-2 Inhibitors on Kidney Function}

Seven studies with 124 patients treated with SGLT-2 inhibitors did not show a significant decline in eGFR between baseline and the end of the study (WMD $=-2.51 \mathrm{~mL} / \mathrm{min} / 1.73 \mathrm{~m}^{2}$ [95\%CI: -5.03 , 0.02]; $p=0.06, \mathrm{I}^{2}=0 \%$ ) (Figure 2).

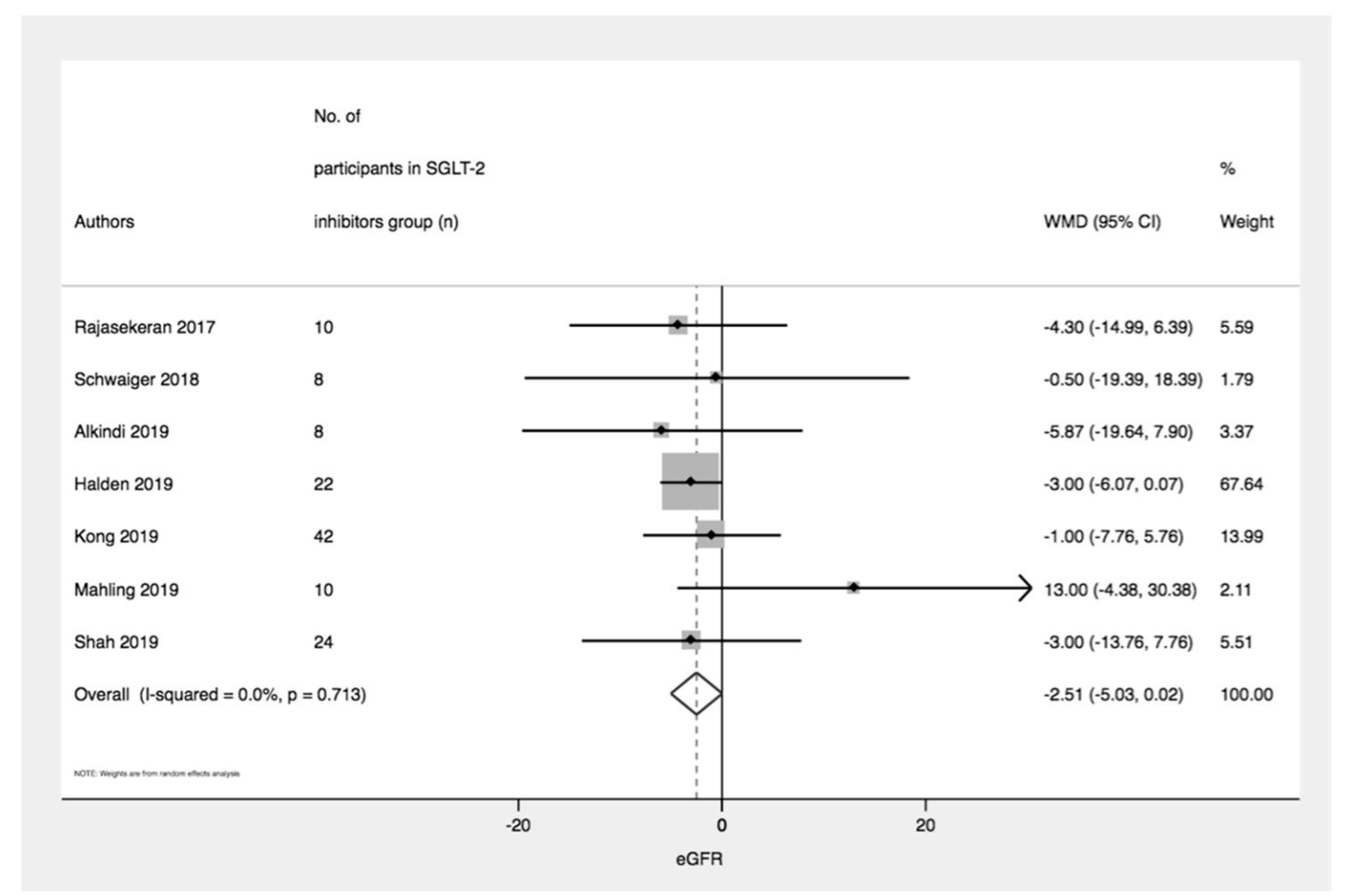

Figure 2. Plot displaying the pooled weighted mean difference of estimated glomerular filtration rate (eGFR), comparing levels at baseline and end of study.

Five studies with 58 participants treated with SGLT-2 inhibitors demonstrated no significant difference in serum creatinine between levels at baseline and at the end of study (WMD $=-0.05 \mathrm{mg} / \mathrm{dl}$ [95\%CI: $-0.12,0.03] ; p=0.21, \mathrm{I}^{2}=0 \%$ ). Three studies with 38 participants treated with SGLT-2 inhibitors reported no significant difference in urine protein creatinine ratio between levels at baseline and end of study (WMD $=-211 \mathrm{mg} / \mathrm{g}[95 \% \mathrm{CI}:-655,232] ; p=0.35, \mathrm{I}^{2}=93.2 \%$ ) (Table 2).

There was no significant decline in eGFR comparing between levels at baseline and at either 6 months among 5 studies with 72 participants (WMD $=-2.38 \mathrm{~mL} / \mathrm{min} / 1.73 \mathrm{~m}^{2}$ [95\% CI: -5.13 , 0.37]; $p=0.09, \mathrm{I}^{2}=0 \%$ ) or between levels at baseline and at 12 months among 4 studies with 68 participants (WMD $=-0.35 \mathrm{~mL} / \mathrm{min} / 1.73 \mathrm{~m}^{2}$ [95\% CI: $\left.-5.66,4.97\right] ; p=0.90, \mathrm{I}^{2}=0 \%$ ). In terms of urine protein creatinine ratio, there was no significant difference between levels at baseline and at 6 months $\left(\mathrm{WMD}=-211 \mathrm{mg} / \mathrm{g}[95 \% \mathrm{CI}:-655,232] ; p=0.35, \mathrm{I}^{2}=93.2 \%\right)$. For serum creatinine, there was no significant difference between levels at baseline and at 12 months (WMD $=-0.05 \mathrm{mg} / \mathrm{dl}$ [95\% CI: -0.15 , $0.05] ; p=0.32, \mathrm{I}^{2}=0 \%$ ) (Table 3).

\subsection{Efficacy of SGLT-2 Inhibitors on Glycated Hemoglobin}

Eight studies with 132 participants treated with SGLT-2 inhibitors demonstrated significantly lower $\mathrm{HbA} 1 \mathrm{C}$ at the end of study compared to baseline (WMD $=-0.57 \%$ [95\% CI: $-0.97,-0.16]$; $p=0.006, \mathrm{I}^{2}=85.2 \%$ ) (Figure 3 and Table 2).

Five studies with 76 participants treated with SGLT-2 inhibitors revealed a significant lower in $\mathrm{HbA} 1 \mathrm{C}$ at 12 months compared to baseline (WMD $=-0.58 \%$ [95\% CI: $-1.12,-0.05] ; p=0.03, \mathrm{I}^{2}=79.8 \%$ ). 
However, comparing HbA1C levels at 6 months and baseline, 5 studies with 72 participants showed no significant difference ( $\mathrm{WMD}=-0.22 \%$ [95\% CI: $-0.62,0.18] ; p=0.28, \mathrm{I}^{2}=41.6 \%$ ) (Table 3).

Table 2. Summary effects of SGLT-2 inhibitors on outcomes of interest among kidney transplant recipients with post-transplant diabetes mellitus, comparing levels at baseline and end of study.

\begin{tabular}{ccccccc}
\hline Parameters & Number of Study & Sample Size & WMD & $\mathbf{9 5 \%}$ CI & $p$-Value & $\mathbf{I}^{\mathbf{2}}$ \\
\hline eGFR & 7 & 124 & $\begin{array}{c}-2.51 \mathrm{~mL} / \mathrm{min} / \\
1.73 \mathrm{~m}^{2}\end{array}$ & $\begin{array}{c}(-5.03,0.02) \\
0.06\end{array}$ & 0 \\
\hline Serum creatinine & 5 & 58 & $-0.05 \mathrm{mg} / \mathrm{dL}$ & $(-0.13,0.03)$ & 0.21 & 0 \\
\hline $\begin{array}{c}\text { Urine protein- } \\
\text { creatinine ratio }\end{array}$ & 3 & 38 & $-211 \mathrm{mg} / \mathrm{g}$ & $(-655,232)$ & 0.35 & 93.2 \\
\hline HbA1C & 8 & 132 & $-0.57 \%$ & $(-0.97,-0.16)$ & 0.006 & 85.2 \\
\hline SBP & 6 & 82 & $-3.24 \mathrm{mmHg}$ & $(-7.92,1.45)$ & 0.18 & 21.3 \\
\hline DBP & 6 & 82 & $-1.49 \mathrm{mmHg}$ & $(-3.81,0.83)$ & 0.21 & 0 \\
\hline BMI & 3 & 38 & $-1.20 \mathrm{~kg} / \mathrm{m}^{2}$ & $(-2.67,0.27)$ & 0.11 & 21.4 \\
\hline Weight & 8 & 132 & $-2.15 \mathrm{~kg}$ & $(-3.07,-1.23)$ & $<0.001$ & 0 \\
\hline
\end{tabular}

eGFR, estimated glomerular filtration rate; HbA1C, glycated hemoglobin; SBP, systolic blood pressure; DBP, diastolic blood pressure; BMI, body mass index; WMD, weighted mean difference; $\mathrm{CI}$, confidence interval.

Table 3. Summary effects of SGLT-2 inhibit ors on outcomes of interest among kidney transplant recipients with post-transplant diabetes mellitus, comparing levels at baseline and 6 months, 12 months, and subgroup analysis on types of SGLT-2 inhibitors.

\begin{tabular}{|c|c|c|c|c|c|c|}
\hline Parameters & Number of Study & Sample Size & WMD & $95 \%$ CI & $p$-Value & $\mathrm{I}^{2}$ \\
\hline \multicolumn{7}{|l|}{ At 6 months } \\
\hline eGFR & 5 & 72 & $\begin{array}{c}-2.38 \mathrm{~mL} / \mathrm{min} / \\
1.73 \mathrm{~m}^{2}\end{array}$ & $(-5.13,0.37)$ & 0.09 & 0 \\
\hline Serum creatinine & & & NA & & & \\
\hline $\begin{array}{l}\text { Urine protein- } \\
\text { creatinine ratio }\end{array}$ & 3 & 38 & $-211 \mathrm{mg} / \mathrm{g}$ & $(-655,232)$ & 0.35 & 93.2 \\
\hline $\mathrm{HbA1C}$ & 5 & 72 & $-0.22 \%$ & $(-0.62,0.18)$ & 0.28 & 41.6 \\
\hline SBP & 4 & 62 & $-6.38 \mathrm{mmHg}$ & $(-15.54,2.80)$ & 0.17 & 64.3 \\
\hline DBP & 4 & 62 & $-2.54 \mathrm{mmHg}$ & $(-6.67,1.59)$ & 0.23 & 47.2 \\
\hline BMI & 3 & 38 & $-0.80 \mathrm{~kg} / \mathrm{m}^{2}$ & $(-1.38,-0.22)$ & 0.007 & 0 \\
\hline Weight & 2 & 46 & $-2.49 \mathrm{~kg}$ & $(-4.15,-0.84)$ & 0.003 & 0 \\
\hline \multicolumn{7}{|l|}{ At 12 months } \\
\hline eGFR & 4 & 68 & $\begin{array}{c}-0.35 \mathrm{~mL} / \mathrm{min} / \\
1.73 \mathrm{~m}^{2}\end{array}$ & $(-5.66,4.97)$ & 0.90 & 0 \\
\hline Serum creatinine & 3 & 24 & -0.05 & $(-0.15,0.05)$ & 0.32 & 0 \\
\hline $\begin{array}{l}\text { Urine protein- } \\
\text { creatinine ratio }\end{array}$ & & & NA & & & \\
\hline $\mathrm{HbA1C}$ & 5 & 76 & $-0.58 \%$ & $(-1.12,-0.05)$ & 0.03 & 79.8 \\
\hline SBP & 3 & 26 & $-7.25 \mathrm{mmHg}$ & $(-16.04,1.54)$ & 0.11 & 0 \\
\hline DBP & 3 & 26 & $-5.24 \mathrm{mmHg}$ & $(-11.19,0.72)$ & 0.09 & 0 \\
\hline BMI & 2 & 16 & $-2.70 \mathrm{~kg} / \mathrm{m}^{2}$ & $(-6.03,0.61)$ & 0.11 & 16.1 \\
\hline Weight & 5 & 76 & $-1.97 \mathrm{~kg}$ & $(-3.21,-0.73)$ & 0.002 & 0 \\
\hline
\end{tabular}


Table 3. Cont.

\begin{tabular}{|c|c|c|c|c|c|c|}
\hline Parameters & Number of Study & Sample Size & WMD & $95 \%$ CI & $p$-Value & $\mathrm{I}^{2}$ \\
\hline \multicolumn{7}{|l|}{ Empagliflozin } \\
\hline eGFR & 3 & 40 & $\begin{array}{c}0.31 \mathrm{~mL} / \mathrm{min} / \\
1.73 \mathrm{~m}^{2}\end{array}$ & $(-8.27,8.88)$ & 0.94 & 37.5 \\
\hline Serum creatinine & 2 & 16 & 0.02 & $(-0.13,0.16)$ & 0.84 & 0 \\
\hline $\begin{array}{l}\text { Urine protein- } \\
\text { creatinine ratio }\end{array}$ & 3 & 38 & $-211 \mathrm{mg} / \mathrm{g}$ & $(-655,232)$ & 0.35 & 93.2 \\
\hline $\mathrm{HbA1C}$ & 4 & 48 & $-0.31 \%$ & $(-0.91,0.28)$ & 0.30 & 92.9 \\
\hline SBP & 3 & 40 & $1.55 \mathrm{mmHg}$ & $(-3.05,6.15)$ & 0.51 & 0 \\
\hline DBP & 3 & 40 & $-1.14 \mathrm{mmHg}$ & $(-5.37,3.09)$ & 0.60 & 15.8 \\
\hline BMI & 2 & 30 & $-0.82 \mathrm{~kg} / \mathrm{m}^{2}$ & $(-1.41,-0.24)$ & 0.006 & 0 \\
\hline Weight & 4 & 48 & $-2.17 \mathrm{~kg}$ & $(-3.20,-1.15)$ & $<0.001$ & 0 \\
\hline \multicolumn{7}{|l|}{ Canagliflozin } \\
\hline eGFR & 2 & 34 & $\begin{array}{c}-3.65 \mathrm{~mL} / \mathrm{min} / \\
1.73 \mathrm{~m}^{2}\end{array}$ & $(-11.24,3.93)$ & 0.35 & 0 \\
\hline Serum creatinine & 2 & 34 & -0.04 & $(-0.16,0.07)$ & 0.48 & 0 \\
\hline $\begin{array}{l}\text { Urine protein- } \\
\text { creatinine ratio }\end{array}$ & & & NA & & & \\
\hline $\mathrm{HbA1C}$ & 2 & 34 & $-0.87 \%$ & $(-1.46,-0.27)$ & 0.004 & 0 \\
\hline SBP & 2 & 34 & $-7.15 \mathrm{mmHg}$ & $(-14.27,-0.03)$ & 0.04 & 0 \\
\hline DBP & 2 & 34 & $-2.49 \mathrm{mmHg}$ & $(-6.87,1.89)$ & 0.27 & 0 \\
\hline BMI & & & NA & & & \\
\hline Weight & 2 & 34 & $-2.14 \mathrm{~kg}$ & $(-4.43,0.16)$ & 0.07 & 0 \\
\hline
\end{tabular}

NA, not applicable.

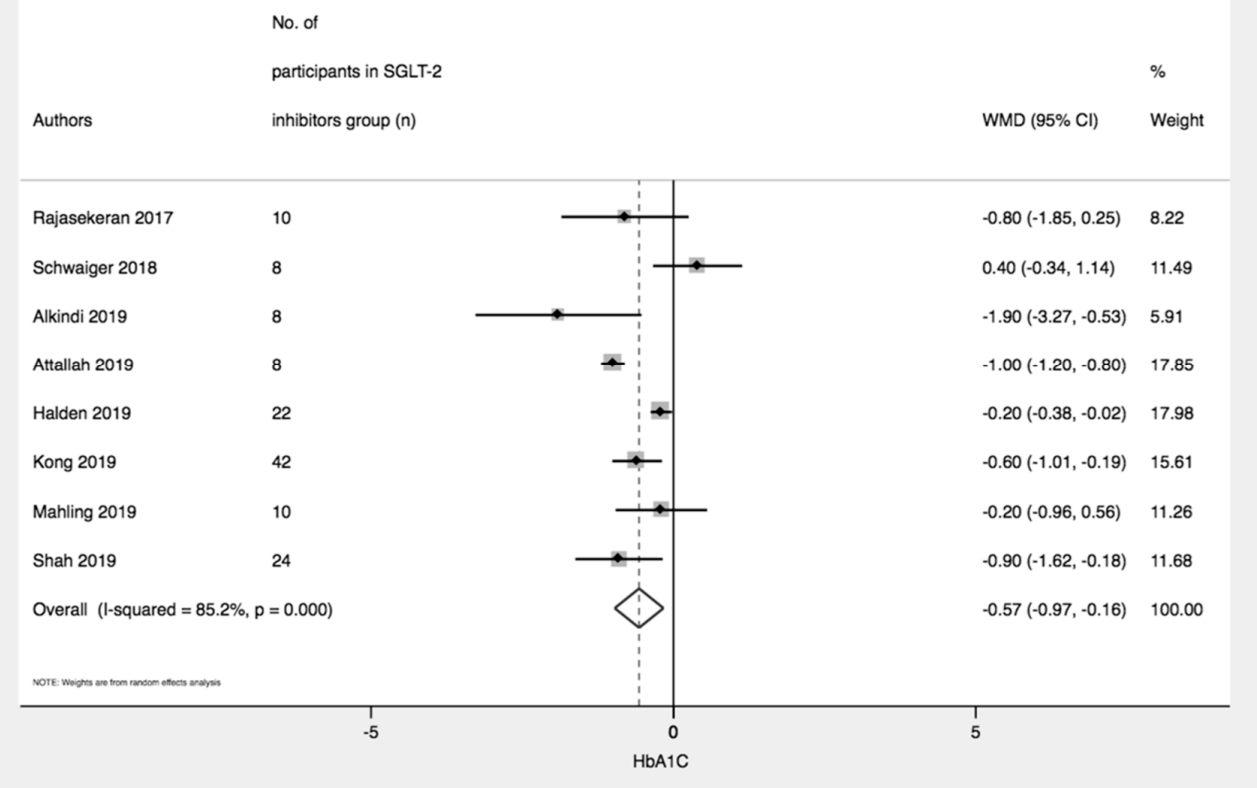

Figure 3. Forest plot displaying the pooled weighted mean difference of glycated hemoglobin (HbA1C), comparing levels at baseline and end of study. 


\subsection{Efficacy of SGLT-2 Inhibitors on Blood Pressure and Body Weight}

Six studies with 82 participants treated with SGLT-2 inhibitors failed to demonstrate significant decline in SBP (WMD $=-3.24 \mathrm{mmHg}$ [95\% CI: $-7.92,1.45] ; p=0.18, \mathrm{I}^{2}=21.3 \%$ ) and DBP $\left(\mathrm{WMD}=-1.49 \mathrm{mmHg}\right.$ [95\% CI: -3.81, 0.83]; $p=0.21, \mathrm{I}^{2}=0 \%$ ). Eight studies with 132 participants treated with SGLT-2 inhibitors demonstrated a significant decrease in body weight between baseline and the end of study (WMD $=-2.15 \mathrm{~kg}$ [95\% CI: $-3.07,-1.23] ; p<0.001, \mathrm{I}^{2}=0 \%$ ). However, there was no significant change in BMI between at baseline and end of study among 3 studies with 38 participants treated with SGLT-2 inhibitors (WMD $=-1.20 \mathrm{~kg} / \mathrm{m}^{2}[95 \% \mathrm{CI}:-2.67,0.27] ; p=0.11, \mathrm{I}^{2}=21.4 \%$ ) (Table 2).

At 6 months, participants treated with SGLT-2 inhibitors had lower BMI (WMD $=-0.80 \mathrm{~kg} / \mathrm{m}^{2}$ [95\% CI: $-1.38,-0.22] ; p=0.007, \mathrm{I}^{2}=0 \%$ ) and body weight (WMD $=-2.49 \mathrm{~kg}[95 \% \mathrm{CI}:-4.15,-0.84]$; $p=0.003, \mathrm{I}^{2}=0 \%$ ) than baseline, while at 12 months, only body weight was significantly lower than baseline (WMD $\left.=-1.97 \mathrm{~kg}[95 \% \mathrm{CI}:-3.21,-0.73] ; p=0.002, \mathrm{I}^{2}=0 \%\right)$ but not BMI $\left(\mathrm{WMD}=-2.70 \mathrm{~kg} / \mathrm{m}^{2}\right.$ [95\% CI: $-6.03,0.61] ; p=0.11, \mathrm{I}^{2}=16.1 \%$ ) (Table 3).

\subsection{Safety Profiles of SGLT-2 Inhibitors}

In total of 8 studies, 14 out of 132 participants had urinary tract infection. One participant out of 72 participants from 5 studies had genital mycosis. No euglycemic ketoacidosis were reported in four studies. Based on 4 studies, 1 out of 28 participants had acute kidney injury. One study reported one small ulcer in lower extremity and another study reported one case of cellulitis. Based on five reported studies, no rejections were found during follow-up period (Table 4).

Table 4. Safety profiles of SGLT-2 inhibitors among kidney transplant recipients with post-transplant diabetes mellitus.

\begin{tabular}{cccccccc}
\hline Authors & $\begin{array}{c}\text { Urinary } \\
\text { Infection }\end{array}$ & $\begin{array}{c}\text { Genital } \\
\text { Mycosis }\end{array}$ & $\begin{array}{c}\text { Euglycemic } \\
\text { Ketoacidosis }\end{array}$ & $\begin{array}{c}\text { Acute Kidney } \\
\text { Injury }\end{array}$ & $\begin{array}{c}\text { Acute } \\
\text { Rejection }\end{array}$ & Ulcer & Cellulitis \\
\hline Rajasekeran 2017 & 0 & 0 & NR & 0 & 0 & NR & 1 \\
\hline Schwaiger 2018 & 3 & 0 & 0 & NR & 0 & NR & NR \\
\hline Alkindi 2019 & 1 & 0 & 0 & 0 & 0 & NR & NR \\
\hline Attallah 2019 & 2 & NR & 0 & 0 & 0 & NR & NR \\
\hline Halden 2019 & 3 & 1 & NR & NR & 0 & NR & NR \\
\hline Kong 2019 & 3 & NR & NR & NR & NR & NR & NR \\
\hline Mahling 2019 & 2 & NR & 0 & 1 & NR & 1 & NR \\
\hline Shah 2019 & 0 & 0 & NR & NR & NR & NR & NR \\
\hline $\begin{array}{c}\text { \%incidence } \\
\text { proportion }\end{array}$ & $43.8 \%$ & $1.4 \%$ & $0 \%$ & $3.6 \%$ & $0 \%$ & $10 \%$ & $10 \%$ \\
\hline
\end{tabular}

NR, not reported.

\subsection{Subgroup Analysis}

In the subgroup analysis for type of SGLT-2 inhibitors, 2 studies with 30 participants treated with empagliflozin demonstrated a lower BMI at end of study compared to baseline (WMD $=-0.82 \mathrm{~kg} / \mathrm{m}^{2}$ [95\% CI: $-1.41,-0.24] ; p=0.006, \mathrm{I}^{2}=0 \%$ ). Four studies with 48 participants treated with empagliflozin showed a lower body weight at end of study compared to baseline (WMD $=-2.17 \mathrm{~kg}$ [95\% CI: -3.20 , $\left.-1.15] ; p<0.001, \mathrm{I}^{2}=0 \%\right)$. There were no significant changes in kidney function, HbA1C, SBP, and DBP between baseline and at end of study among participants treated with empagliflozin. On the other hand, 2 studies with 34 participants treated with canagliflozin reported a significant decline in $\mathrm{HbA} 1 \mathrm{C}$ $(\mathrm{WMD}=-0.87 \%$ [95\% CI: $\left.-1.46,-0.27] ; p=0.004, \mathrm{I}^{2}=0 \%\right)$ and SBP (WMD $=-7.15 \mathrm{mmHg}$ [95\% CI: $\left.-14.27,-0.03] ; p=0.04, \mathrm{I}^{2}=0 \%\right)$. There were no significant changes in kidney functions, BMI, and body weight between baseline and at end of study among participants treated with canagliflozin (Table 3). 


\subsection{Assessment of Publication bias}

The Egger's test for our main primary outcome of eGFR change between levels at baseline and end of study was not significant $(p=0.08)$. Moreover, a funnel plot for eGFR of the included studies did not suggest any asymmetry. Therefore, publication bias was less likely to occur in our meta-analysis (Figure 4).
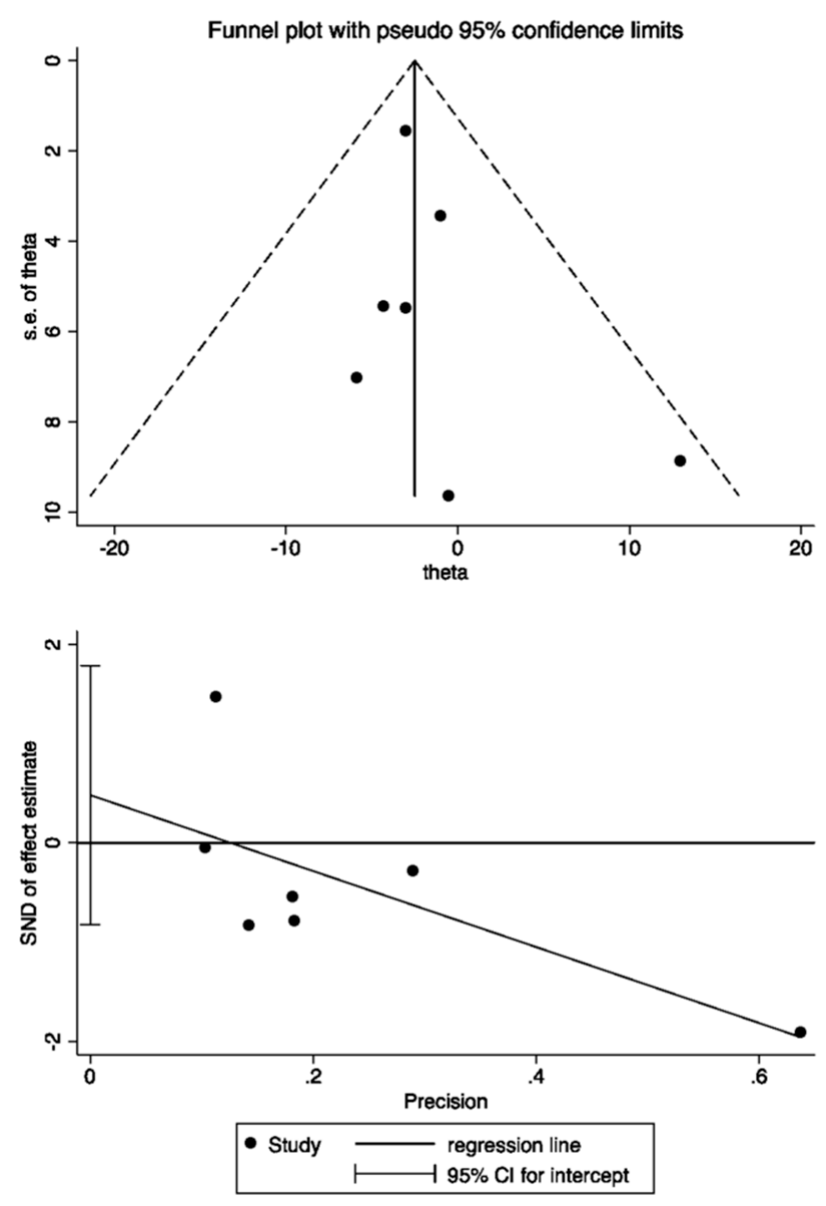

Figure 4. Assessment for publication bias by Funnel plot and Egger test.

\section{Discussion}

Our study is the first meta-analysis to demonstrate the efficacy and safety of SGLT-2 inhibitors in treating kidney transplant recipients with DM. SGLT-2 inhibitors effectively lowered HbA1C when treated for at least 12 months and reduced body weight when treated for at least 6 months. Moreover, eGFR, serum creatinine levels, and urine protein-creatinine ratio among patients treated with SGLT-2 inhibitors were stable throughout the follow-up period. Empagliflozin revealed efficacy in reducing body weight, while canagliflozin showed efficacy in diminishing $\mathrm{HbA1C}$ and SBP. Reported adverse effects of SGLT-2 inhibitors included urinary tract infection (43.8\%), small ulcers in lower extremities $(10 \%)$, cellulitis $(10 \%)$, AKI $(3.6 \%)$, and genital fungal infection (1.4\%), respectively. No euglycemic ketoacidosis and acute rejection events were reported.

SGLT-2 inhibitors inhibit sodium-glucose reabsorption at proximal renal tubules, causing osmotic diuresis and natriuresis [15]. As a result, the glucose and HbA1C levels drop [15,26]. However, this glycemic efficacy was modest and limited by the filtered load of glucose and the osmotic diuresis [16,17]. A recent meta-analysis of SGLT-2 inhibitors among diabetic non-kidney transplant patients with chronic kidney disease demonstrated a modest reduction in $\mathrm{HbA1C}$, body weight, and albuminuria [57]. Our findings among kidney transplant recipients suggested similar effects 
except for albuminuria. The modest effect in lowering $\mathrm{HbA} 1 \mathrm{C}$ of around $0.6 \%$ in our kidney transplant recipients with DM was consistent with previously reported mean reduction ranging between 0.4 and $1.1 \%$ among general diabetic patients $[16,17]$. In light of body weight, previous literature reported a weight loss of 2 to $3 \mathrm{~kg}$ among diabetic patients treated with SGLT-2 inhibitors [17,58]. This finding aligns with our result of $2 \mathrm{~kg}$ weight reduction. Although we pooled data mostly from case series, our findings suggested similar efficacy of SGLT-2 inhibitors between kidney transplant recipients with DM and the non-kidney transplant diabetic population $[17,58]$. In terms of preserving kidney functions, our study did not show a significant change of eGFR, serum creatinine, and urine protein. Even though it is possible that the follow-up times ( 6 to 12 months) were not long enough to observe these differences, at least during these periods of follow-up, there was no worsening kidney function among kidney transplant recipients with DM treated with SGLT-2. Previous major clinical trials of empagliflozin (EMPA-REG OUTCOME) and canagliflozin (CANVAS Program) suggested a benefit of SGLT-2 inhibitors in reducing progression of proteinuria [40,59]. However, due to limited data, we did not have control groups and thus we could not conclude whether treated with SGLT-2 inhibitors helps slow the progression of proteinuria among kidney transplant recipients with DM.

In terms of blood pressure, theoretically, a decrease in body weight combined with osmotic diuresis and reduction of total body sodium can result in lowering blood pressure around 4-6 $\mathrm{mmHg}$ in SBP and 1-2 mmHg in DBP, as shown in non-kidney transplant patients with DM [60]. However, our study demonstrated no significant reduction in blood pressure among kidney transplant recipients treated with SGLT-2 inhibitors. This could be explained by more complicated pathogenic mechanisms of hypertension among kidney transplant recipients, including but not limited to side effects from immunosuppressive regimens and the presence of native kidneys [43,61]. Another possible explanation is the insufficient sample size to detect these differences. Although we observed the reduction of SBP among those treated with canagliflozin but not empagliflozin, these incongruent effects might be explained by different baseline characteristics such as higher eGFR and shorter transplant duration, which might reflect a better graft function among canagliflozin group compared to empagliflozin.

In addition to the effect on diminishing intraglomerular hyperfiltration and hypertension, SGLT-2 inhibitors also demonstrate anti-inflammatory, antifibrotic, and protective effects against deregulation of extracellular matrix evidenced by a reduction in serum levels of TNF receptor 1, IL-6, matrix metalloproteinase 7, and fibronectin 1 [62]. Moreover, SGLT-2 inhibitors also reduce serum level of leptin, c-reactive protein, and IL-1 $\beta$ secretion via ROS-NLRP3-caspase-1 pathway [63,64]. Furthermore, SGLT-2 inhibitors also showed antioxidative effects via activation of SIRT1/AMPK, suppression of Akt/mTOR signaling pathway [65]. Some studies also found a decreased level in myeloperoxidase among SGLT-2 inhibitors group, suggesting a lower oxidative damage to vascular endothelium [66]. These potential effects of SGLT-2 inhibitors might benefit kidney transplant recipients in which inflammation and fibrosis are the major process in allograft rejection.

In light of safety profiles of SGLT-2 inhibitors among kidney transplant recipients with DM, the incidence of urinary tract infection was $43.8 \%$ in our study vs. $38.0 \%$ among general kidney transplant recipients [67], which was not significantly different $(p=0.13)$. This was supported by previous meta-analysis of non-kidney transplant diabetic population, which revealed an increased risk of genital infection but found no significant increased risk of urinary tract infection [68]. In our study, we found $1.4 \%$ of genital mycosis. However, due to limited data, we did not have a control group or incidence reported among general kidney transplant recipients to compare. SGLT-2 inhibitors have been found to be associated with a higher risk of euglycemic ketoacidosis via the mechanism involving the decrease in insulin and increase glucagon secretion, which stimulates a shift of glucose to fat metabolism and promotes ketogenesis $[29,69]$. Nevertheless, studies included in our meta-analysis did not report any euglycemic ketoacidosis events. However, it is possible that sample size or follow-up time was not adequate to capture this event. Slight increase in serum creatinine with early reductions in eGFR (of $\sim 4 \mathrm{~mL} / \mathrm{min} / 1.73 \mathrm{~m}^{2}$ ) during the first $~ 3-6$ weeks of treatment SGLT-2 inhibitors has been observed among non-kidney transplant patients, and data has supported this [26,70]. Lowering 
serum creatinine and increasing eGFR after discontinuation of SGLT-2 inhibitors suggest functional nature of the GFR reduction induced by these drugs [26,70]. Nevertheless, a case of biopsy-proven osmotic nephrosis in a non-kidney transplant patient with DM treated with canagliflozin was recently reported [71]. While our study demonstrated the incidence of AKI of 3.6\% among kidney transplant recipients treated with SGLT-2 inhibitors, data on allograft kidney biopsy are limited and require further study.

There are some limitations in our meta-analysis. Firstly, included studies were mostly case series without a control group, and the sample size was fairly small. Secondly, the median time of follow-up was 12 months. Hence, some complications might not be have been observed during 1-2 years of follow-up. Moreover, we did not have a control group to compare to, so given the design of each study and insufficient data from each study, we could not adjust for potential confounders such as concomitant antidiabetic medications and duration of diabetes. Furthermore, the data on cardiovascular outcomes were lacking. Therefore, large randomized controlled trials with long-term follow-up are required to investigate the effects of SGLT-2 inhibitors on outcomes after kidney transplantation, including cardiovascular events, delayed graft rejection and mortality risk, as well as safety profiles such as hypovolemia [72]. Conversely, several strengths should be highlighted. First, subgroup analyses allowed us to investigate the effect of SGLT-2 inhibitors based upon type of SGLT-2 inhibitors and change of each parameter at 6 and 12 months. Additionally, we performed random-effects model and searched for heterogeneity by incorporating additional sources of variability between studies to make our results more robust given possible different backgrounds of population in each study.

\section{Conclusions}

In conclusion, our study suggested that SGLT-2 inhibitors were effective in lowering $\mathrm{HbA} 1 \mathrm{C}$ when treated at least 12 months, reducing body weight when treated at least 6 months, and preserving kidney function among kidney transplant recipients with DM without reported serious adverse events, including euglycemic ketoacidosis and acute rejection. Based on our findings, future randomized controlled trials are required to further investigate the efficacy and safety of SGLT-2 inhibitors, including long-term allograft and patient survival.

Supplementary Materials: The following are available online at http://www.mdpi.com/2076-3271/8/4/47/s1, Search terms used in each database.

Author Contributions: Conceptualization, A.C., C.T., J.M., S.V., and W.C.; Data curation, A.C., N.P., and W.C.; Formal analysis, A.C.; Investigation, A.C., N.P., and W.C.; Methodology, A.C., N.P., C.T., and W.C.; Project administration, T.B.; Resources, T.B.; Software, A.C.; Supervision, C.T., T.B., J.M., S.V., and W.C.; Validation, A.C., N.P., C.T., and W.C.; Visualization, A.C.; Writing-original draft, A.C.; Writing-review and editing, A.C., N.P., C.T., T.B., J.M., S.V., and W.C. All authors have read and agreed to the published version of the manuscript.

Funding: This research received no external funding.

Conflicts of Interest: The authors declare no conflict of interest.

\section{References}

1. Koye, D.N.; Magliano, D.J.; Nelson, R.G.; Pavkov, M.E. The Global Epidemiology of Diabetes and Kidney Disease. Adv. Chronic Kidney Dis. 2018, 25, 121-132. [CrossRef]

2. Hart, A.; Smith, J.M.; Skeans, M.A.; Gustafson, S.K.; Wilk, A.R.; Robinson, A.; Wainright, J.L.; Haynes, C.R.; Snyder, J.J.; Kasiske, B.L.; et al. OPTN/SRTR 2016 Annual Data Report: Kidney. Arab. Archaeol. Epigr. 2018, 18, 18-113. [CrossRef] [PubMed]

3. Cosio, F.G.; Pesavento, T.E.; Kim, S.; Osei, K.; Henry, M.; Ferguson, R.M. Patient survival after renal transplantation: IV. Impact of post-transplant diabetes. Kidney Int. 2002, 62, 1440-1446. [CrossRef] [PubMed]

4. Kasiske, B.L.; Snyder, J.J.; Gilbertson, D.; Matas, A.J. Diabetes Mellitus after Kidney Transplantation in the United States. Arab. Archaeol. Epigr. 2003, 3, 178-185. [CrossRef] 
5. Woodward, R.S.; Schnitzler, M.A.; Baty, J.D.; Lowell, J.A.; Lopez-Rocafort, L.; Haider, S.; Woodworth, T.G.; Brennan, D.C. Incidence and Cost of New Onset Diabetes Mellitus Among U.S. Wait-Listed and Transplanted Renal Allograft Recipients. Arab. Archaeol. Epigr. 2003, 3, 590-598. [CrossRef]

6. Shivaswamy, V.; Boerner, B.; Larsen, J. Post-Transplant Diabetes Mellitus: Causes, Treatment, and Impact on Outcomes. Endocr. Rev. 2016, 37, 37-61. [CrossRef]

7. Paek, J.H.; Kang, S.S.; Park, W.Y.; Jin, K.; Park, S.B.; Han, S.; Kim, C.-D.; Ro, H.; Lee, S.; Jung, C.W.; et al. Incidence of Post-transplantation Diabetes Mellitus Within 1 Year After Kidney Transplantation and Related Factors in Korean Cohort Study. Transplant. Proc. 2019, 51, 2714-2717. [CrossRef]

8. Eide, I.A.; Halden, T.A.S.; Hartmann, A.; Dahle, D.O.; Åsberg, A.; Jenssen, T. Associations Between Posttransplantation Diabetes Mellitus and Renal Graft Survival. Transplantation 2017, 101, 1282-1289. [CrossRef]

9. Dienemann, T.; Fujii, N.; Li, Y.; Govani, S.; Kosaraju, N.; Bloom, R.D.; Feldman, H.I. Long-term patient survival and kidney allograft survival in post-transplant diabetes mellitus: A single-center retrospective study. Transpl. Int. 2016, 29, 1017-1028. [CrossRef]

10. Cooper, L.; Oz, N.; Fishman, G.; Shohat, T.; Rahamimov, R.; Mor, E.; Green, H.; Grossman, A. New onset diabetes after kidney transplantation is associated with increased mortality-A retrospective cohort study. Diabetes/Metab. Res. Rev. 2017, 33, e2920. [CrossRef]

11. Kuo, H.-T.; Sampaio, M.S.; Vincenti, F.; Bunnapradist, S. Associations of Pretransplant Diabetes Mellitus, New-Onset Diabetes After Transplant, and Acute Rejection with Transplant Outcomes: An Analysis of the Organ Procurement and Transplant Network/United Network for Organ Sharing (OPTN/UNOS) Database. Am. J. Kidney Dis. 2010, 56, 1127-1139. [CrossRef] [PubMed]

12. Valderhaug, T.G.; Hjelmesæth, J.; Hartmann, A.; Røislien, J.; Bergrem, H.A.; Leivestad, T.; Line, P.D.; Jenssen, T. The association of early post-transplant glucose levels with long-term mortality. Diabetologia 2011, 54, 1341-1349. [CrossRef] [PubMed]

13. Galindo, R.J.; Fried, M.; Breen, T.; Tamler, R. HYPERGLYCEMIA MANAGEMENT IN PATIENTS WITH POSTTRANSPLANTATION DIABETES. Endocr. Pract. 2016, 22, 454-465. [CrossRef]

14. Lo, C.; Jun, M.; Badve, S.V.; Pilmore, H.; White, S.L.; Hawley, C.; Cass, A.; Perkovic, V.; Zoungas, S. Glucose-lowering agents for treating pre-existing and new-onset diabetes in kidney transplant recipients. Cochrane Database Syst. Rev. 2017. [CrossRef]

15. Heerspink, H.J.L. Sodium glucose co-transporter 2 inhibition: A new avenue to protect the kidney. Nephrol. Dial. Transplant. 2019, 34, 2015-2017. [CrossRef]

16. Musso, G.; Gambino, R.; Cassader, M.; Pagano, G. A novel approach to control hyperglycemia in type 2 diabetes: Sodium glucose co-transport (SGLT) inhibitors. Systematic review and meta-analysis of randomized trials. Ann. Med. 2011, 44, 375-393. [CrossRef]

17. Clar, C.; Gill, J.A.; Court, R.; Waugh, N. Systematic review of SGLT2 receptor inhibitors in dual or triple therapy in type 2 diabetes. BMJ Open 2012, 2, e001007. [CrossRef]

18. Daniele, G.; Solis-Herrera, C.; Dardano, A.; Mari, A.; Tura, A.; Giusti, L.; Kurumthodathu, J.J.; Campi, B.; Saba, A.; Bianchi, A.M.; et al. Increase in endogenous glucose production with SGLT2 inhibition is attenuated in individuals who underwent kidney transplantation and bilateral native nephrectomy. Diabetologia 2020, 63, 2423-2433. [CrossRef]

19. Chao, E.C.; Henry, R.R. SGLT2 inhibition-A novel strategy for diabetes treatment. Nat. Rev. Drug Discov. 2010, 9, 551-559. [CrossRef]

20. Nauck, M.A. Update on developments with SGLT2 inhibitors in the management of type 2 diabetes. Drug Des. Dev. Ther. 2014, 8, 1335-1380. [CrossRef]

21. Anderson, S.; Cotiguala, L.; Tischer, S.; Park, J.M.; McMurry, K. Review of Newer Antidiabetic Agents for Diabetes Management in Kidney Transplant Recipients. Ann. Pharmacother. 2020, 1060028020951955. [CrossRef] [PubMed]

22. Kanduri, S.R.; Kovvuru, K.; Hansrivijit, P.; Thongprayoon, C.; Vallabhajosyula, S.; Pivovarova, A.I.; Chewcharat, A.; Garla, V.V.; Medaura, J.; Cheungpasitporn, W. SGLT2 Inhibitors and Kidney Outcomes in Patients with Chronic Kidney Disease. J. Clin. Med. 2020, 9, 2723. [CrossRef] [PubMed]

23. Song, C.C.; Brown, A.; Winstead, R.; Yakubu, I.; Demehin, M.; Kumar, D.; Gupta, G. Early initiation of sodium-glucose linked transporter inhibitors (SGLT-2i) and associated metabolic and electrolyte outcomes in diabetic kidney transplant recipients. Endocrinol. Diabetes Metab. 2020, e00185. [CrossRef] 
24. Zelniker, T.A.; Wiviott, S.D.; Raz, I.; Im, K.; Goodrich, E.L.; Bonaca, M.P.; Mosenzon, O.; Kato, E.T.; Cahn, A.; Furtado, R.H.M.; et al. SGLT2 inhibitors for primary and secondary prevention of cardiovascular and renal outcomes in type 2 diabetes: A systematic review and meta-analysis of cardiovascular outcome trials. Lancet 2019, 393, 31-39. [CrossRef]

25. Liu, X.-Y.; Zhang, N.; Chen, R.; Zhao, J.-G.; Yu, P. Efficacy and safety of sodium-glucose cotransporter 2 inhibitors in type 2 diabetes: A meta-analysis of randomized controlled trials for 1 to 2 years. J. Diabetes Complicat. 2015, 29, 1295-1303. [CrossRef] [PubMed]

26. Vergara, A.; Jacobs-Cachá, C.; Soler, M.J. Sodium-glucose cotransporter inhibitors: Beyond glycaemic control. Clin. Kidney J. 2019, 12, 322-325. [CrossRef]

27. Nadkarni, G.N.; Ferrandino, R.; Chang, A.; Surapaneni, A.; Chauhan, K.; Poojary, P.; Saha, A.; Ferket, B.; Grams, M.E.; Coca, S.G. Acute Kidney Injury in Patients on SGLT2 Inhibitors: A Propensity-Matched Analysis. Diabetes Care 2017, 40, 1479-1485. [CrossRef]

28. Watts, N.B.; Bilezikian, J.P.; Usiskin, K.; Edwards, R.; Desai, M.; Law, G.; Meininger, G. Effects of Canagliflozin on Fracture Risk in Patients with Type 2 Diabetes Mellitus. J. Clin. Endocrinol. Metab. 2016, 101, 157-166. [CrossRef]

29. Peters, A.; Buschur, E.O.; Buse, J.B.; Cohan, P.; Diner, J.C.; Hirsch, I.B. Euglycemic Diabetic Ketoacidosis: A Potential Complication of Treatment with Sodium-Glucose Cotransporter 2 Inhibition. Diabetes Care 2015, 38, 1687-1693. [CrossRef]

30. Chang, H.-Y.; Singh, S.; Mansour, O.; Baksh, S.; Alexander, G.C. Association Between Sodium-Glucose Cotransporter 2 Inhibitors and Lower Extremity Amputation Among Patients with Type 2 Diabetes. JAMA Intern. Med. 2018, 178, 1190-1198. [CrossRef]

31. Neal, B.; Perkovic, V.; Mahaffey, K.W.; De Zeeuw, D.; Fulcher, G.; Erondu, N.; Shaw, W.; Law, G.; Desai, M.; Matthews, D.R. Canagliflozin and Cardiovascular and Renal Events in Type 2 Diabetes. N. Engl. J. Med. 2017, 377, 644-657. [CrossRef]

32. Perkovic, V.; De Zeeuw, D.; Mahaffey, K.W.; Fulcher, G.; Erondu, N.; Shaw, W.; Barrett, T.D.; Weidner-Wells, M.; Deng, H.; Matthews, D.R.; et al. Canagliflozin and renal outcomes in type 2 diabetes: Results from the CANVAS Program randomised clinical trials. Lancet Diabetes Endocrinol. 2018, 6, 691-704. [CrossRef]

33. Yale, J.; Bakris, G.; Cariou, B.; Nieto, J.; David-Neto, E.; Yue, D.; Wajs, E.; Figueroa, K.; Jiang, J.; Law, G.; et al. Efficacy and safety of canagliflozin over 52 weeks in patients with type 2 diabetes mellitus and chronic kidney disease. Diabetes Obes. Metab. 2014, 16, 1016-1027. [CrossRef] [PubMed]

34. Perkovic, V.; Jardine, M.J.; Neal, B.; Bompoint, S.; Heerspink, H.J.; Charytan, D.M.; Edwards, R.; Agarwal, R.; Bakris, G.; Bull, S.; et al. Canagliflozin and Renal Outcomes in Type 2 Diabetes and Nephropathy. N. Engl. J. Med. 2019, 380, 2295-2306. [CrossRef] [PubMed]

35. Kohan, D.E.; Fioretto, P.; Tang, W.; List, J.F. Long-term study of patients with type 2 diabetes and moderate renal impairment shows that dapagliflozin reduces weight and blood pressure but does not improve glycemic control. Kidney Int. 2014, 85, 962-971. [CrossRef]

36. Fioretto, P.; Del Prato, S.; Buse, J.B.; Goldenberg, R.; Giorgino, F.; Reyner, D.; Langkilde, A.M.; Sjöström, C.D.; Sartipy, P.; on behalf of the DERIVE Study Investigators. Efficacy and safety of dapagliflozin in patients with type 2 diabetes and moderate renal impairment (chronic kidney disease stage 3A): The DERIVE Study. Diabetes Obes. Metab. 2018, 20, 2532-2540. [CrossRef] [PubMed]

37. Wiviott, S.D.; Raz, I.; Bonaca, M.P.; Mosenzon, O.; Kato, E.T.; Cahn, A.; Silverman, M.G.; Zelniker, T.A.; Kuder, J.F.; Murphy, S.A.; et al. Dapagliflozin and Cardiovascular Outcomes in Type 2 Diabetes. N. Engl. J. Med. 2019, 380, 347-357. [CrossRef]

38. Martinez, F.A.; Serenelli, M.; Nicolau, J.C.; Petrie, M.C.; Chiang, C.-E.; Tereshchenko, S.; Solomon, S.D.; Inzucchi, S.E.; Køber, L.; Kosiborod, M.N.; et al. Efficacy and Safety of Dapagliflozin in Heart Failure with Reduced Ejection Fraction According to Age. Circulation 2020, 141, 100-111. [CrossRef]

39. Cherney, D.Z.I.; Dekkers, C.C.J.; Barbour, S.J.; Cattran, D.; Gafor, A.H.A.; Greasley, P.J.; Laverman, G.D.; Lim, S.K.; Di Tanna, G.L.; Reich, H.N.; et al. Effects of the SGLT2 inhibitor dapagliflozin on proteinuria in non-diabetic patients with chronic kidney disease (DIAMOND): A randomised, double-blind, crossover trial. Lancet Diabetes Endocrinol. 2020, 8, 582-593. [CrossRef]

40. Zinman, B.; Wanner, C.; Lachin, J.M.; Fitchett, D.H.; Bluhmki, E.; Hantel, S.; Mattheus, M.; Devins, T.; Johansen, O.E.; Woerle, H.J.; et al. Empagliflozin, Cardiovascular Outcomes, and Mortality in Type 2 Diabetes. N. Engl. J. Med. 2015, 373, 2117-2128. [CrossRef] [PubMed] 
41. Häring, H.-U.; Merker, L.; Seewaldt-Becker, E.; Weimer, M.; Meinicke, T.; Woerle, H.J.; Broedl, U.C.; on behalf of the EMPA-REG METSU Trial Investigators. Empagliflozin as Add-on to Metformin Plus Sulfonylurea in Patients with Type 2 Diabetes: A 24-week, randomized, double-blind, placebo-controlled trial. Diabetes Care 2013, 36, 3396-3404. [CrossRef]

42. Barnett, A.H.; Mithal, A.; Manassie, J.; Jones, R.; Rattunde, H.; Woerle, H.J.; Broedl, U.C. Efficacy and safety of empagliflozin added to existing antidiabetes treatment in patients with type 2 diabetes and chronic kidney disease: A randomised, double-blind, placebo-controlled trial. Lancet Diabetes Endocrinol. 2014, 2, 369-384. [CrossRef]

43. Halden, T.A.S.; Kvitne, K.E.; Midtvedt, K.; Rajakumar, L.; Robertsen, I.; Brox, J.; Bollerslev, J.; Hartmann, A.; Åsberg, A.; Jenssen, T. Efficacy and Safety of Empagliflozin in Renal Transplant Recipients with Posttransplant Diabetes Mellitus. Diabetes Care 2019, 42, 1067-1074. [CrossRef]

44. Allegretti, A.S.; Zhang, W.; Zhou, W.; Thurber, T.K.; Rigby, S.P.; Bowman-Stroud, C.; Trescoli, C.; Serusclat, P.; Freeman, M.W.; Halvorsen, Y.-D.C. Safety and Effectiveness of Bexagliflozin in Patients with Type 2 Diabetes Mellitus and Stage 3a/3b CKD. Am. J. Kidney Dis. 2019, 74, 328-337. [CrossRef]

45. Wheeler, D.C.; Stefansson, B.V.; Batiushin, M.; Bilchenko, O.; Cherney, D.Z.I.; Chertow, G.M.; Douthat, W.; Dwyer, J.P.; Escudero, E.; Pecoits-Filho, R.; et al. The dapagliflozin and prevention of adverse outcomes in chronic kidney disease (DAPA-CKD) trial: Baseline characteristics. Nephrol. Dial. Transplant. 2020, 35, 1700-1711. [CrossRef]

46. Lo, C.; Toyama, T.; Oshima, M.; Jun, M.; Chin, K.L.; Hawley, C.M.; Zoungas, S. Glucose-lowering agents for treating pre-existing and new-onset diabetes in kidney transplant recipients. Cochrane Database Syst. Rev. 2020. [CrossRef]

47. Moher, D.; Liberati, A.; Tetzlaff, J.; Altman, D.G.; The PRISMA Group. Preferred Reporting Items for Systematic Reviews and Meta-Analyses: The PRISMA Statement. PLoS Med. 2009, 6, e1000097. [CrossRef]

48. National Heart Lung and Blood Institute. Study Quality Assessment Tools. Available online: https: //www.nhlbi.nih.gov/health-topics/study-quality-assessment-tools (accessed on 14 December).

49. Higgins, J.P.T.; Thompson, S.G.; Deeks, J.J.; Altman, D.G. Measuring inconsistency in meta-analyses. BMJ 2003, 327, 557-560. [CrossRef]

50. Rajasekeran, H.; Kim, J.S.; Cardella, C.J.; Schiff, J.; Cattral, M.; Cherney, D.Z.; Singh, S.K. Use of Canagliflozin in Kidney Transplant Recipients for the Treatment of Type 2 Diabetes: A Case Series. Diabetes Care 2017, 40, e75-e76. [CrossRef]

51. Schwaiger, E.; Burghart, L.; Signorini, L.; Ristl, R.; Kopecky, C.; Tura, A.; Pacini, G.; Wrba, T.; Antlanger, M.; Schmaldienst, S.; et al. Empagliflozin in posttransplantation diabetes mellitus: A prospective, interventional pilot study on glucose metabolism, fluid volume, and patient safety. Arab. Archaeol. Epigr. 2019, 19, 907-919. [CrossRef] [PubMed]

52. Alkindi, F.; Al-Omary, H.L.; Hussain, Q.; Al Hakim, M.; Chaaban, A.; Boobes, Y. Outcomes of SGLT2 Inhibitors Use in Diabetic Renal Transplant Patients. Transplant. Proc. 2020, 52, 175-178. [CrossRef]

53. Attallah, N.; Yassine, L. Use of Empagliflozin in Recipients of Kidney Transplant: A Report of 8 Cases. Transplant. Proc. 2019, 51, 3275-3280. [CrossRef] [PubMed]

54. Mahling, M.; Schork, A.; Nadalin, S.; Fritsche, A.; Heyne, N.; Guthoff, M. Sodium-Glucose Cotransporter 2 (SGLT2) Inhibition in Kidney Transplant Recipients with Diabetes Mellitus. Kidney Blood Press. Res. 2019, 44, 984-992. [CrossRef] [PubMed]

55. Shah, M.; Virani, Z.; Rajput, P.; Shah, B. Efficacy and Safety of Canagliflozin in Kidney Transplant Patients. Indian J. Nephrol. 2019, 29, 278-281. [CrossRef] [PubMed]

56. Kong, J.; Joon, J.; Chul, Y.; Eun, W.; Hyuk, K.; Hyun, S.S. SP770SODIUM/GLUCOSE COTRANSPORTER 2 INHIBOTOR FOR THE TREATMENT OF DIABETES IN KIDNEY TRANSPLANT PATIENTS. Nephrol. Dial. Transplant. 2019, 34. [CrossRef]

57. Toyama, T.; Neuen, B.L.; Jun, M.; Ohkuma, T.; Neal, B.; Jardine, M.J.; Heerspink, H.L.; Wong, M.G.; Ninomiya, T.; Wada, T.; et al. Effect of SGLT2 inhibitors on cardiovascular, renal and safety outcomes in patients with type 2 diabetes mellitus and chronic kidney disease: A systematic review and meta-analysis. Diabetes Obes. Metab. 2019, 21, 1237-1250. [CrossRef]

58. Foote, C.; Perkovic, V.; Neal, B. Effects of SGLT2 inhibitors on cardiovascular outcomes. Diabetes Vasc. Dis. Res. 2012, 9, 117-123. [CrossRef] 
59. Ceriello, A.; Ofstad, A.P.; Zwiener, I.; Kaspers, S.; George, J.; Nicolucci, A. Empagliflozin reduced long-term $\mathrm{HbA1c}$ variability and cardiovascular death: Insights from the EMPA-REG OUTCOME trial. Cardiovasc. Diabetol. 2020, 19, 176. [CrossRef]

60. Sahebkar, A.; Atkin, S.L.; Sahebkar, A. Mechanistic effects of SGLT2 inhibition on blood pressure in diabetes. Diabetes Metab. Syndr. Clin. Res. Rev. 2019, 13, 1679-1683. [CrossRef]

61. Weir, M.R.; Burgess, E.D.; Cooper, J.E.; Fenves, A.Z.; Goldsmith, D.; McKay, D.; Mehrotra, A.; Mitsnefes, M.M.; Sica, D.A.; Taler, S.J. Assessment and Management of Hypertension in Transplant Patients. J. Am. Soc. Nephrol. 2015, 26, 1248-1260. [CrossRef] [PubMed]

62. Heerspink, H.J.L.; Perco, P.; Mulder, S.; Leierer, J.; Hansen, M.K.; Heinzel, A.; Mayer, G. Canagliflozin reduces inflammation and fibrosis biomarkers: A potential mechanism of action for beneficial effects of SGLT2 inhibitors in diabetic kidney disease. Diabetologia 2019, 62, 1154-1166. [CrossRef] [PubMed]

63. Hattori, S. Anti-inflammatory effects of empagliflozin in patients with type 2 diabetes and insulin resistance. Diabetol. Metab. Syndr. 2018, 10, 1-7. [CrossRef] [PubMed]

64. Sahebkar, A.; Simental-Mendía, L.E.; Banach, M.; Bo, S.; Sahebkar, A. The major molecular mechanisms mediating the renoprotective effects of SGLT2 inhibitors: An update. Biomed. Pharmacother. 2019, 120, 109526. [CrossRef]

65. Packer, M. SGLT2 Inhibitors Produce Cardiorenal Benefits by Promoting Adaptive Cellular Reprogramming to Induce a State of Fasting Mimicry: A Paradigm Shift in Understanding Their Mechanism of Action. Diabetes Care 2020, 43, 508-511. [CrossRef] [PubMed]

66. Iannantuoni, F.; De Marañon, A.M.; Diaz-Morales, N.; Falcon, R.; Bañuls, C.; Abad-Jiménez, Z.; Victor, V.M.; Hernández-Mijares, A.; Rovira-Llopis, S. The SGLT2 Inhibitor Empagliflozin Ameliorates the Inflammatory Profile in Type 2 Diabetic Patients and Promotes an Antioxidant Response in Leukocytes. J. Clin. Med. 2019, 8,1814 . [CrossRef]

67. Wu, X.; Dong, Y.; Liu, Y.; Li, Y.; Sun, Y.; Wang, J.; Wang, S. The prevalence and predictive factors of urinary tract infection in patients undergoing renal transplantation: A meta-analysis. Am. J. Infect. Control. 2016, 44, 1261-1268. [CrossRef]

68. Liu, J.; Li, L.; Li, S.; Jia, P.; Deng, K.; Chen, W.; Sun, X. Effects of SGLT2 inhibitors on UTIs and genital infections in type 2 diabetes mellitus: A systematic review and meta-analysis. Sci. Rep. 2017, 7, 1-11. [CrossRef]

69. Lee, P.C.; Ganguly, S.; Goh, S.-Y. Weight loss associated with sodium-glucose cotransporter-2 inhibition: A review of evidence and underlying mechanisms. Obes. Rev. 2018, 19, 1630-1641. [CrossRef]

70. Nespoux, J.; Vallon, V. SGLT2 inhibition and kidney protection. Clin. Sci. 2018, 132, 1329-1339. [CrossRef]

71. Phadke, G.; Kaushal, A.; Tolan, D.R.; Hahn, K.; Jensen, T.; Bjornstad, P.; Roncal-Jimenez, C.; Hernando, A.A.; Lanaspa, M.A.; Alexander, M.P.; et al. Osmotic Nephrosis and Acute Kidney Injury Associated with SGLT2 Inhibitor Use: A Case Report. Am. J. Kidney Dis. 2020, 76, 144-147. [CrossRef] [PubMed]

72. Menne, J.; Dumann, E.; Haller, H.; Schmidt, B.M.W. Acute kidney injury and adverse renal events in patients receiving SGLT2-inhibitors: A systematic review and meta-analysis. PLoS Med. 2019, 16, e1002983. [CrossRef] [PubMed]

Publisher's Note: MDPI stays neutral with regard to jurisdictional claims in published maps and institutional affiliations.

(C) 2020 by the authors. Licensee MDPI, Basel, Switzerland. This article is an open access article distributed under the terms and conditions of the Creative Commons Attribution (CC BY) license (http://creativecommons.org/licenses/by/4.0/). 